\title{
Decentraliserad välfärd eller medborgerliga rättigheter? Om omfördelning av makt och ansvar mellan stat och kommun
}

\author{
ÅKE BERGMARK \& RENATE MINAS
}

I Sverige, liksom i övriga Europa, har det över de senaste decennierna skett en överföring av makt och ansvar från nationalstat till lokalsamhälle. Detta reser frägor om demokrati, nationellt garanterade medborgerliga rättigheter och betydelsen av kommunala variationer i välfärdstjänsternas tillgänglighet och kvalitet. I artikeln analyseras utvecklingen

i Sverige under de senaste decennierna mot bakgrund av förändringar i lagstiftning och former för statlig styrning. Genomgången visar bl. a. att staten återtagit initiativet $p a ̊$ många områden i ingången av 2000-talet och decentralisering inte längre är den entydigt dominerande trenden.

\section{Inledning}

Frågan om hur makt och ansvar skall förde-

Åke Bergmark, professor i socialt arbete vid Mittuniversitet i Östersund samt forskningsledare vid Institutet för Framtidsstudier i Stockholm.

Renate Minas, Fil.dr. i socialt arbete och forskare vid Institutet för Framtidsstudier i Stockholm. las mellan nationalstat och lokalsamhälle har under senare år vunnit ökad aktualitet i takt med att de flesta västländer bevittnat en utveckling där befogenheterna hos regioner och kommuner gradvis ökat i omfång (se t.ex. Gidlund \& Jerneck 2000, Pollitt 2005, Henman \& Fenger 2006). Inom den Europeiska unionen har dessutom natio- 
nalstatens makt utmanats av supranationella avtal och bestämmelser, som inte bara anger ramar för hur den nationella politiken kan utformas utan också inlemmar denna i en gemensam europeisk agenda (Leibfried \& Pierson 1995, Bache \& Flinders 2004). I takt med att makt förskjuts åt ett antal olika nivåer så upprättas också nya typer av mer eller mindre institutionaliserade samarbeten mellan olika aktörer - det sammanlagda resultatet av de komplexa nätverk som då utvecklas benämns ofta som multi-level governance (Hooghe \& Marks 2001, Treib et al. 2005). . Inom ramen för denna process har det också skett en förskjutning av vertikal makt mellan olika politiska och administrativa nivåer i samhället. Den dominerande trenden har här på nationell nivå varit decentralisering, dvs. en förflyttning av makt och ansvar från överordnade (t.ex. staten) till lägre nivåer (t.ex. kommuner). Vissa beslut har dock gått i motsatt riktning och inneburit en förstärkning av nationalstatens inflytande, dvs. verkat recentraliserande. Det senare har emellertid i såväl Sverige som Europa i övrigt främst beskrivits som ett undantag - i de allra flesta fall är decentralisering och utökade lokala befogenheter det dominerande temat.

Begreppet rescaling har använts för att understryka att den vertikala omfördelning av makt som sker inte bara är en gradvis förskjutning, utan någonting som i grunden förändrar förutsättningarna för såväl socialpolitiken som marknadens mekanismer

1 Någon allmänt vedertagen översättning av detta begrepp finns inte. Omväxlande används dock i olika sammanhang "flernivåstyrning", "flernivådemokrati» eller "flernivåsystem».
(Brenner 2004, Jessop 2002). ${ }^{2}$ Att nationalstaten utmanas som den viktigaste eller demokratiskt sett mest ändamålsenliga politiska organisationsformen handlar dock inte enbart om decentralisering på nationell nivå, utan också om att nationella regeringar får avträda makt och befogenheter åt överstatliga nivåer. Vid sidan av maktförskjutningar uppåt och nedåt utmanas också nationalstaten av nya konfigurationer där lokala aktörer lierar sig över nationsgränserna med andra lokala aktörer eller med olika supranationella organ - emellanåt beskrivet som glokalisering (Swyngedouw 2004). Ytterst få är dock beredda att, ens på sikt, avskriva den nationella nivån helt och hållet. Istället talar man om en "relativisering" av nivåer, eftersom det dominerande statliga initiativet inte tydligt ersätts av någon annan nivå eller aktör (Jessop 2005, Mahon 2006).

Som medborgare i Sverige i dag kan man ha politiskt valda företrädare på upp till sex olika nivåer, allt ifrån representation inom den Europeiska Unionen ned till ledamöter på kommun- eller stadsdelsnivå (Nilsson 2004). När det gäller verkställigheten så är emellertid spridningen mindre omfattande. Det mesta av det vi idag i Sverige benämner som välfärdstjänster handlar om verksamheter som utförs och finansieras av kommuner och landsting, på lokal respektive regional nivå. Utmärkande för Sverige,

2 Inte heller detta begrepp har någon självklar svensk översättning. Inom statsvetenskap utnyttjas emellanåt "maktförskjutning", men de konnotationer som följer av detta motsvarar inte helt det engelska begreppet (som vid sidan av makt bl. a. också inbegriper fördelning av ansvar).

Åke Bergmark \& Renate Minas: Decentraliserad välfärd eller medborgerliga rättigheter? 
liksom för övriga nordiska länder, är att vi i jämförelse med övriga Västeuropa har få och förhållandevis stora kommuner. Andra kännetecken är att utgifterna för kommunernas verksamhet svarar för en större del av såväl BNP som de samlade offentliga utgifterna (Lidström 2003). Vidare präglas svenska kommuner av jämförelsevis stor självständighet och av att det politiska beslutsfattandet är relativt oberoende av den nationella politiken. I jämförelse med andra länder har den regionala nivån en förhållandevis svag ställning och den svenska samhällsorganisationen brukar emellanåt liknas vid ett timglas, där den regionala nivån representerar midjan medan toppen och basen utgörs av stat respektive kommuner (SOU 1998:166). Under decennier har utvecklingen här också präglats av beslut som kan beskrivas som decentraliserande - mängden uppgifter för den lokala sektorn har under lång tid ökat och lagstiftningen har på många håll givit kommuner och landsting ökat handlingsutrymme (Lidström \& Kolam 2003).

I allt väsentligt saknas emellertid mer uppdaterade beskrivningar av utvecklingen och i synnerhet då med avseende på vad som händer på välfärdstjänsteområdet. Vi vet inte med säkerhet om antagandet om en fortgående decentralisering är gångbart vid ingången till 2000-talet eller i vilka avseenden som relationen stat-kommun fortsätter att förändras. Själva området har dock en hög aktualitet, inte minst mot bakgrund av Ansvarskommitténs slutbetänkande där frågan om den statliga styrningen av kommunsektorn givits en mycket framträdande roll (SOU 2007:10). En av de frågor som hamnat i fokus är hur avvägningen mellan det kommunala självstyrets princip och rätten till likabehandling eller likvärdig service oberoende var man bor, skall hanteras. I föreliggande artikel skall vi, med ett huvudsakligt fokus på de tre senaste decennierna, närmare beskriva och analysera utvecklingen i Sverige när det gäller rescaling, dvs. de- och recentraliseringsrörelser med relevans för så kallade välfärdstjänster. Framställningen har ett fokus mot territoriell de- och recentralisering. I vissa sammanhang inryms också funktionella förskjutningar i begreppsparet, då syftande på i vilken utsträckning beslutsfattande och ansvar förläggs på specialiserade enheter (Pollit 2005). Vi kommer också i huvudsak att behandla beslut och reformer som påverkat relationen stat-kommun, och ägna mindre intresse åt exempelvis landstingen eller utbudet av sjukvård. Vi kommer inte heller att ägna oss åt den inomkommunala decentralisering som etablerats genom införande av stads- eller kommundelsnämnder.

Eftersom argumentationen för ett utökat kommunalt självstyre och en fortgående decentralisering under lång tid kan sägas ha satt dagordningen för den svenska debatten kommer vi inleda vår beskrivning av ideologiska förutsättningar och institutionella ramar med utgångspunkt från detta. Vi kommer emellertid också att behandla alla de invändningar som formulerats samt de händelser som drivit utvecklingen åt ett annat håll.

\section{Decentralisering: drivkrafter och motstånd}

I sin mest grundläggande betydelse beskri- 
ver begreppet decentralisering en förskjutning av makt och ansvar från högre till lägre nivåer i samhället. Det handlar med andra ord om en förflyttning av politiska och administrativa befogenheter från centrala till mer lokala sfärer eller, om man så vill, ett tillbakadragande av nationalstatens ansvarstagande till förmån för lokalt inflytande. Vid sidan om detta finns en mängd olika uttolkningar av begreppet (Lundquist 1972, Pierre 1987), och vad som är att betrakta som hög respektive låg decentraliseringsgrad varierar i hög utsträckning med olika författares preferenser när det gäller lokalt inflytande (Page 1991). Det förekommer också specifikationer, t.ex. med avseende på politisk, administrativ, territoriell, funktionell, intern eller extern decentralisering (Pollitt 2005). Av dessa är distinktionen politisk-administrativ kanske den i det här sammanhanget mest intressanta. Den första beskriver en formell överflyttning av beslutanderätt från exempelvis riksdag till kommunfullmäktige. Den andra inbegriper beslut som på olika sätt ger tjänstemän på olika positioner ett större handlingsutrymme, till exempel genom en minskad detaljreglering i lagstiftningen.

Så här långt i artikeln har vi ett antal gånger använt begreppsparet "makt och ansvarı för att beskriva vad det är som förflyttas. Detta är högst avsiktligt och går tillbaka på två olika dimensioner i decentraliseringsprocessen. Decentralisering av makt är i stort sett liktydigt med politisk decentralisering och innebär att kommunerna själva ges ökad beslutanderätt över den lokala välfärdspolitikens mål och inriktning. Kommunerna får därmed en större frihet att bestämma såväl vad som skall göras som hur insatserna skall utformas. Decentralisering av ansvar innebär att verkställigheten av välfärdspolitiska beslut fattade på central nivå i högre grad förläggs på det lokala planet. Här kan staten bibehålla kontroll över verksamheternas mål och utförande, samtidigt som kommuner och landsting åläggs ett slags redovisningsansvar gentemot statsmakten.

Vilka bevekelsegrunder har då funnits för en utökning av ansvar och befogenheter för den lokala sektorn? Vi kan här återfinna ideologiska, ekonomiska och politiskt-strategiska motiv. ${ }^{3}$ När det gäller utvecklingens ideologiska grundvalar finns det skäl att peka på att decentralisering med tiden har kommit att bli ett inte bara mycket gångbart begrepp i det politiska språket, utan också något av ett honnörsord mot vilket ytterst få har haft några invändningar. ${ }^{4}$ Decentralisering i betydelsen ökat lokalt inflytande har i Sverige förordats från såväl höger som vänster under de senaste decennierna (Premfors 1996), ofta utifrån antaganden om en utvidgad demokratisk bas. Föreställningen om decentralisering som ett sätt att fördjupa och förstärka den

3 Viktigt att påpeka här att det vid sidan om argumentationen för eller emot ett ökat lokalt ansvarstagande också finns en debatt som handlar om (i huvudsak) för- respektive nackdelarna med att sprida beslutsfattande och ansvar på ett flertal aktörer istället för att samla den på en enda nivå (Hooghe \& Marks 2003).

4 Argumentationen för ett (utökat) lokalt självstyre har dessutom djupa historiska rötter, med företrädare som John Stuart Mill, Alexis de Tocqueville och Michail Bakunin, som alla trots ideologiska olikheter förordat en utökad lokal makt (Pettersson 2001).

Åke Bergmark \& Renate Minas: Decentraliserad välfärd eller medborgerliga rättigheter? 
offentliga demokratin är mycket väletablerad, liksom tilltron till de lokala enheternas förmåga att anpassa verksamheterna till medborgarnas önskemål och behov. Mer än annat vilar demokratiargumentet på uppfattningen att kommunal självstyrelse för beslutsfattandet närmare medborgarna och att man därmed uppnår en bättre överensstämmelse mellan människors önskemål och den offentliga verksamhetens innehåll. Den representativa lokala demokratin och möjligheterna att på denna nivå utkräva ansvar vad gäller den genomförda politiken anses ge en väsentligt bättre anläggningsyta gentemot folkviljan än vad som uppnås genom nationella val. Parallellt finns också föreställningar om att en närhet till beslutsfattandet stärker medborgarnas medvetenhet om det demokratiska styrelseskicket och att den därför också bidrar till ett ökat engagemang (SOU 1998:166, SOU 1999:97). Decentraliseringsargumentet har också framförts i debatten om välfärdsstatens legitimitet (Rothstein 2001). Det har funnits en kritik som går ut på att den offentliga förvaltningen präglas av maktfullkomlighet och att den fjärmar sig alltmer från medborgarnas behov. De legitimitetsproblem som härigenom uppstår anses bäst motverkas genom att beslut och ansvar förs ned närmare medborgarna. Genom decentralisering kan verksamheten bättre anpassas till medborgarnas faktiska behov vilket, i sin förlängning, antas leda till att det politiska engagemanget ökar.

Utöver de demokratiska argumenten finns också ett antal bevekelsegrunder av mer instrumentell karaktär. Centralstyrning beskrivs $\mathrm{i}$ många sammanhang som kostsam, ineffektiv och byråkrati- genererande i jämförelse med en decentraliserad förvaltning (Pierre 1987, Putnam 1993). Det kortare avståndet mellan beslut och verkställighet i det lokala självstyret förväntas leda till tidsbesparingar, färre mellanled och ökad effektivitet. Antagandet om ökad effektivitet har dock så här långt inte gått att belägga empiriskt (John 2004).

Ett annat närliggande, men mer långsiktigt, argument tar fasta på den mångfald som kan uppstå ur en mer självständig lokal praxis. Tanken är att frihet från tvingande nationella standards leder till förnyelse och möjligheter att utveckla verksamheten genom systematiska jämförelser mellan olika modeller (Sharpe 1970). Decentralisering kan också vara ett led i statens försök att spara pengar (Sharpe 1988, Pierre \& Peters 2000). När lokala organ tar över inte bara huvudmannaskap, utan också det finansiella ansvaret för verksamheterna kan balansen i statsbudgeten förbättras - förutsatt att en full kompensation via ökade statsbidrag inte sker.

De Vrijes (2000) har i en komparativ studie visat att ju större ett land är till ytan, desto större är stödet för decentralisering bland lokala beslutsfattare. I samma studie framkommer att lokala beslutsfattare framförallt är benägna att förorda en långtgående decentralisering på områden där de själva är verksamma. Det senare är i linje med det i politisk teori vanliga antagandet att politiska och administrativa aktörer strävar efter att maximera sitt eget inflytande (Christensen 2000). En ökande decentralisering kan då ses som ett uttryck för att lokala beslutsfattare varit framgångsrika i denna strävan. 
Vilka argument talar då mot en fortgående decentralisering och vad finns det för skäl att bibehålla statligt inflytande på det lokala självstyrets bekostnad? Med statens övergripande ansvar för välfärden i landet följer också ett åtagande som innebär att vissa lägstanivåer när det gäller tillgänglighet, service eller individuella levnadsförhållanden inte får underskridas. Det innebär till exempel att skolan förväntas hålla en viss standard eller att det ekonomiska biståndet inte underskrider en given norm. Genom att fastställa tak (maxtaxor) för olika typer av avgifter kan staten också försäkra sig om att tillgängligheten för vissa tjänster inte begränsas för mycket. Sammanhängande med definierade lägstanivåer är förväntningarna på ett visst mått av lika service eller likvärdig standard oberoende av var i riket man bor. Betydande skillnader i faktisk välfärd eller i möjligheter att få vård och omsorg som avgörs av på vilken sida av kommungränsen man bor, kan i många sammanhang uppfattas som ett rättviseproblem eller som en avvikelse från den universalitet på vilken den svenska välfärdsmodellen vilar (Rauch 2005). Argumentationen för likabehandling kan också utsträckas till de system där krav på motprestationer från brukare/klienter förekommer, till exempel i socialbidragshanteringen eller i de delar av den aktiva arbetsmarknadspolitiken som övertagits av kommunerna (Bergmark 2001).

Decentraliserat ansvar i sig innebär dock inte med nödvändighet att nationellt beslutade lägstanivåer underskrids eller att variationen ökar oacceptabelt mycket. Det är framförallt när lokala mål och prioriteringar avviker från de nationella som utvecklingen
- åtminstone med statens ögon - kan bli problematisk (Lundin \& Skedinger 2000). Målkonflikter av detta slag kan till exempel uppstå när kommuner, trängda av ett minskande ekonomiskt utrymme, prioriterar sparmål och budgetbalans framför nationellt fastlagda välfärdsmål. Kommunala variationer i välfärdens kvalitet eller tillgänglighet kan också följa av att de nationella målen formulerats allt för vagt eller av att kompetensen på den lokala nivån är för låg. Det förra är ett förhållande som potentiellt ökat i betydelse i takt med att detaljlagstiftning ersatts av ramlagar och målstyrning (Hansen 1997). Det senare kan delvis hänföras till att tjänstemän och politiker på den lokala nivån i många fall förväntas kunna hantera en mängd olika lagstiftningar, vilket leder till att specialistkompetensen - och rättssäkerheten för den enskilde - kan bli lägre än i ett centraliserat system (Tideman 2000).

Stödet för ett tydligt statligt ansvarstagande, garanterade lägstanivåer och en någorlunda likartad tillgänglighet oberoende av kommuntillhörighet har ofta också formulerats med det sociala medborgarskapet som utgångspunkt. Socialt medborgarskap är ett begrepp som är förknippat med den engelska sociologen T H Marshall och bygger på föreställningen att alla människor har visa grundläggande sociala rättigheter, allt från rätten till ekonomiskt välfärd och säkerhet till att fullt delta i det sociala livet i enlighet med samhällets rådande standard. Den moderna välfärdsstaten handlar i grunden om att öka de sociala rättigheterna genom att erbjuda ett system av transfereringar och tjänster som sörjer för att alla medborgare har någon slags grund-

Åke Bergmark \& Renate Minas: Decentraliserad välfärd eller medborgerliga rättigheter? 
läggande ekonomiskt trygghet och tillgång till tjänster som t.ex. skola, sjukvård eller äldreomsorg. Sociala rättigheter innebär också att det finns förväntningar på tillgång på lika villkor oavsett var man bor i landet. Både nationell likvärdighet och kommunalt självstyre kan betraktas som viktiga inslag i den svenska modellen och balansen mellan nationalstatens krav på likabehandling och kommunernas strävan efter självständighet och handlingsutrymme står under ständig omprövning. I argumentationen för det förra påtalas kommunernas ibland självsvåldiga attityd och förekomsten av domstolstrots (Panican \& Sunesson 2004). I en karakteristik över hur medborgarrätten åsidosatts inom ramen för det kommunala självbestämmandet talar Sunesson (1999) om »det lokala självstyrets arrogans».

En förklaring till varför centralmakten verkar för decentralisering erbjuder idén om så kallad blame avoidance, vilket i detta sammanhang innebär att politiker frivilligt avhänder sig ansvar för områden där man förutser att impopulära beslut kan bli nödvändiga, t.ex. i form av nedskärningar (Hooghe \& Marks 2001, Pierson 2004). I praktiken behöver detta emellertid inte innebära en distinkt överföring av ansvar och befogenheter från en nivå till en annan. Följden kan lika gärna vara en mer allmän otydlighet i var ansvaret egentligen ligger och vem som ytterst kan ställas till svars för hur välfärdstjänsterna fungerar. Som en bidragande faktor till denna otydlighet i ansvar har också utvecklingen av nya och allt mer komplexa nätverk mellan olika aktörer pekats ut (Flinders 2001). Här talar man emellanåt om institutionell fragmentering (Pierson 1995, Leibfried \& Pierson
1995). Begreppet inbegriper rent allmänt den otydlighet och splittring som uppstår när beslutsfattande på ett eller flera områden förläggs till olika nivåer, men har i praktiken framförallt kommit att beskriva vad som sker när sub-nationella aktörer fullföljer egna intressen i strid med nationella mål och därigenom utmanar nationalstatens auktoritet.

I kritiken mot decentralisering av offentliga verksamheter tillbakavisas ofta också idén om att ökat lokalt inflytande skulle medföra en högre grad av effektivitet. Bättre kunskaper om lokala förhållanden åtföljs inte självklart av en god kunskapsnivå när det gäller komplexiteten i de sakfrågor som berörs. Den närhet och flexibilitet som det lokala sammanhanget i bästa fall erbjuder kompenserar inte, menar man, för den kompetensuttunning som följer när strategiska beslut sprids på för många händer (Segal 1997). Vidare hävdas att utvecklingen av lokala modeller inte självklart leder till mångfald och förnyelse, utan lika gärna till upprepningar av tidigare prövade grepp och att tid och energi förbrukas på att "återuppfinna hjulet»(de Vrijes 2000).

\section{Sverige och det kommunala självstyret}

Framväxten av välfärdsstaten under efterkrigstiden innebar att den kommunala sektorn kom att växa i omfång och betydelse, samtidigt som de verksamheter som utvecklades och ålades kommunerna i huvudsak var ett resultat av beslut som fattats på nationell nivå. Det innebär å ena sidan att kommunerna på ett helt annat 
sätt än tidigare etablerades som betydelsefulla administrativa och politiska enheter men å andra sidan att detta var en tillväxt under villkor som staten $i$ allt väsentligt bestämde. Resultatet var en integration av den kommunala sfären i välfärdsstaten (Seip 1991) och att relationen stat-kommun under modern tid kommit att ha en avgörande betydelse för utformningen av vård och omsorg.

I grundlagen fastslås att den svenska folkstyrelsen skall förverkligas genom »...ett representativt statsskick och genom kommunal självstyrelse» (RF 1 kap 1 §). Andra bestämmelser i Regeringsformen tilldelar emellertid riksdagen rätt att genom lagstiftning inskränka och utvidga kommunernas uppgifter och politiska manöverutrymme. Också av förarbetena till 1974 års grundlagsreform framgår att lagstiftaren medvetet argumenterade för att formerna för kommunal självstyrelse inte närmare skall anges (Strandberg 2000). I den proposition om ny Regeringsform som överlämnades till riksdagen 1973 skrev det föredragande statsrådet på följande sätt:

I vårt land präglas förhållandet mellan kommunerna och statsmakterna och därmed den kommunala självstyrelsen av en helhetssyn. Generellt gäller sålunda att staten och kommunerna samverkar $p a ̊$ skilda områden och $i$ olika former för att uppnå gemensamma mål. Utgår man från detta synsätt, är det varken lämpligt eller möjligt att en gång för alla dra orubbliga eller preciserade gränser $i$ grundlag kring en kommunal självstyrelsesektor. Arbetsoch befogenhetsfördelningen mellan stat och kommun måste istället i ganska vid omfatt- ning kunna ändras $i$ takt med samhällsut vecklingen (prop. 1973:90 s. 190).

Eftersom någon ovillkorlig kommunal handlingsfrihet inte är stadfäst så saknar kommunerna egentlig möjlighet att åberopa grundlagens portalparagraf i syfte att hävda sin rätt till självstyrelse eller påvisa (statligt) åsidosättande av densamma (Birgersson \& Wallin 1977). Denna inskränkning har, tillsammans med det faktum att merparten av de uppgifter som kommunerna handhar är ålagda dem av staten, fått vissa författare att mena att »kommunal självstyrelse« är ett oegentligt begrepp och att till exempel »självförvaltning" är en mer adekvat beteckning (Montin 1996).

För att kunna förstå hur kommuner orienterar sig inom ramen för regelverk och ekonomiska/politiska realiteter kan det finnas anledning att göra en distinktion mellan handlingsfrihet och handlingsutrymme, där det förra representerar vad kommunerna får göra och det senare vad de kan göra (Lidström 1991). Genom lagstiftning sätts ramarna för friheten, medan sådant som tid, resurser, etik och politiska förhållanden avgör hur utrymmet ser ut $i$ praktiken (Sveriges Kommuner och Landsting 2005).

\section{Former för statlig styrning}

Ser vi till de delar av den svenska välfärdssektorn som kommunerna ålagts att sköta, kan vi konstatera att de i varierande grad befinner sig under statlig kontroll. Denna kontroll utövas genom ett antal olika styrinstrument, vars verkan kan beskrivas som

Åke Bergmark \& Renate Minas: Decentraliserad välfärd eller medborgerliga rättigheter? 
mer eller mindre direkt eller tvingande. Den utveckling mot ökad decentralisering som vi bevittnat under senare decennier innebär primärt en övergång till styrning av mer indirekt och mindre detaljerad art - inte att statens kontroll undandras helt och hållet. Strävan att minska den statliga detaljregleringen har, oberoende av politisk majoritet, funnits hos statsmakten alltsedan 1970-talet (Gustafsson 1999).

Vilka är då de styrinstrument som staten förfogar över? Med en viss förenkling kan vi urskilja tre huvudsakliga former av statlig styrning:

- Författningsstyrning

- Finansiell styrning

- Nationella organ för tillsyn och implementering

Mest betydelsefull är otvivelaktigt styrning genom lagar och förordningar, så kallad författningsstyrning. Av de författningar som reglerar den kommunala verksamheten är vissa av allmänt konstitutiv art, medan andra - en majoritet - är inriktade mot enskilda sektorer (Westerståhl 1987). Exempel på det förra är Regeringsformen och Kommunallagen. Sektorsinriktade författningar utgörs av speciallagar som t.ex. Socialtjänstlagen eller Skollagen. Uppskattningsvis 80 procent av kommunernas samlade resurser används till ändamål som regleras av speciallagar (Nilsson \& Westerståhl 1997). De lagar som behandlar specifika sektorer varierar med avseende på hur stora delar av verksamheten som behandlas och hur detaljerade bestämmelserna är. På många områden har så kallade ramlagar kommit att ersätta tidigare detaljreglering. Exempel på detta är t.ex. Socialtjänstlagen och Hälso- och sjukvårdslagen. En betydelsefull del av den rättsliga regleringen handlar om hur den enskildes rättigheter formuleras i de sektorsinriktade författningarna och vilka beslut som kan överklagas genom så kallat förvaltningsbesvär. Statens inflytande definieras här å ena sidan genom hur stora delar av de kommunala besluten gentemot enskilda som blir möjliga att överklaga och å andra sidan genom vilka beslut som de facto fattas i förvaltningsdomstolarna. Besluten i Regeringsrätten kan i praktiken många gånger ses som preciseringar av mer generella skrivningar i lagstiftningen.

Staten kan också reglera kommunernas verksamhet med hjälp av ekonomiska styrmedel. Här är utformningen av statsbidragen ett av de viktigaste inslagen. Något förenklat kan man säga att specialdestinerade bidrag till särskilda områden innebär en högre grad av styrning än generella bidrag avsedda för hela den kommunala verksamheten. En annan betydelsefull ekonomisk styrform erbjuds genom statens möjligheter att bestämma över omfattningen av kommunernas skatteinkomster. Riksdagen kan av såväl samhällsekonomiska som fördelningspolitiska skäl anse det motiverat med ett tak för kommunalskatten under vissa perioder. Vidare representerar det kommunala utjämningssystemet en form av ekonomisk styrning (Riksrevisionsverket 1996a). Syftet med utjämningen är primärt att skapa mer likvärdiga ekonomiska villkor för kommuner med olikartade strukturella förutsättningar.

För en mer direkt styrning av de kommunala verksamheterna är organisationen av nationella (centrala ämbetsverk) och regionala statliga organ (länsstyrelser) 
det kanske viktigaste inslaget. Här utgör implementering och tillsyn huvudsakliga uppgifter. För välfärdspolitiken kan man framförallt peka på Skolverkets ansvar för skola och barnomsorg samt Socialstyrelsens ansvar för hälso- och sjukvård samt socialtjänst. Ämbetsverken utgår i sitt arbete från befintlig lagstiftning, verksamhetsmål och effektmål preciserade i statsbudgeten samt från de regleringsbrev som bl.a. föreskriver vilken återrapporteringsskyldighet som föreligger i förhållande till staten. Vid sidan om tillsynen förväntas också de statliga verken förse kommunerna med information och riktlinjer på ett sätt som överensstämmer med statens intentioner.

Oavsett styrmedel, så kan graden av detaljreglering variera. Ett särdrag när det gäller utvecklingen under 1980- och 1990talen är att så kallad mål- och resultatstyrning $\mathrm{i}$ många sammanhang kom att ersätta mer specifika föreskrifter. Med detta begränsas det statliga ansvaret $i$ allt väsentligt till att formulera målsättningar för olika verksamheter, medan man i efterhand följer upp i vilken utsträckning verksamheternas resultat motsvarar målen. Kommunerna väljer dock självständigt vilka medel som skall utnyttjas för att uppnå de mål som angivits. Formellt görs i vissa sammanhang en åtskillnad mellan målstyrning och resultatstyrning, med innebörden att den förra mer riktas mot övergripande mål och den senare mot mer specifika prestationer (Riksrevisionsverket 1996b). Övergången från detaljreglering till mål- och resultatstyrning är inte isolerad till någon specifik del av det statliga styrsystemet, utan har på olika sätt präglat utvecklingen på alla nivåer och för alla styrinstrument.
Noterbart när det gäller statens styrning av kommunsektorn är att Ansvarskommittén i sitt slutbetänkande (SOU 2007:10) förordar en renodling av styrinstrumenten, med innebörden att styrning via allmänna råd, riktade ekonomiska medel eller andra ej bindande instrument bör begränsas medan normering i lagar, förordningar och myndigheters föreskrifter bör vara den mest framträdande styrformen.

\section{Välfärdens territoriella tyngdpunkt: decentralisering eller recentralisering?}

Hur kan då utvecklingen i Sverige under de senaste decennierna beskrivas? Handlar det om en enkelriktad utveckling mot ökat kommunalt självstyre eller kan vi iaktta tecken på att utvecklingen har vänt? Pollitt (2005) påpekar att de- och recentraliseringsrörelser ofta uppträder simultant och enskilda reformer ofta kan inrymma såväl det ena som det andra. Att sammanfattande söka beskriva utvecklingen innebär därför alltid en risk för förenklingar eller missvisande generaliseringar. $\mathrm{Vi}$ menar emellertid att vissa institutionella förändringar under de senaste decennierna har en relativt tydlig riktning när det gäller maktoch ansvarsförskjutningar. De kan då indelas enligt följande:

\section{Decentralisering}

Ovan antyddes att utvecklingen fram till 1990-talets mitt till övervägande del präglats av beslut som utökat det lokala ansva-

Åke Bergmark \& Renate Minas: Decentraliserad välfärd eller medborgerliga rättigheter? 
ret och vidgat kommunernas handlingsfrihet. Det finns också ett antal reformer som mycket tydligt pekat i den riktningen. På en mer övergripande nivå är införandet av en ny kommunallag 1992 (KL 1991:900) en av de viktigaste händelserna under perioden. Med denna lag gavs kommunerna större befogenheter att självständigt utforma sin interna organisation. Bland annat övergavs tidigare bestämmelser avseende hur de kommunala nämnderna skulle se ut, samtidigt som möjligheterna att delegera beslut till nämnder, enskilda ledamöter och tjänstemän ökade. Omfattande organisatoriska förändringar följde också i kommunerna. Visserligen präglades verksamheten redan tidigare av täta organisationsbyten, men med den nya lagen ökade takten och förändringarna kom allt mer att inbegripa den grundläggande nämndstrukturen. I mitten av 1990-talet hade två tredjedelar av kommunerna övergivit den traditionella sektorsindelningen för sina nämnder. Det totala antalet nämnder i landet minskade också som en följd av att kommuner av effektivitetsskäl valde att slå samman tidigare specialnämnder i mer övergripande beslutsorgan (SOU 1996:169).

Andra viktiga förändringar handlar om överflyttning av huvudmannaskap. Några av de mest betydelsefulla förändringarna under senare tid har inneburit en överföring från landstingssektorn till kommunerna. Den mest betydelsefulla var den så kallade Ädelreformen 1992 med vilken kommunerna övertog det samlade ansvaret för äldreomsorgen. Tidigare hade landstingen haft ansvar för medicinskt färdigbehandlade men vårdkrävande patienter inom ramen för sjukhem och långvård.
Kommunerna kompenserades ekonomiskt för reformen genom att drygt 20 miljarder kronor överfördes från landstingen via skatte- och bidragsväxling. I kölvattnet på Ädelreformen genomfördes ett par huvudmannaskapsförändringar med likartad innebörd. Handikappreformen, som trädde i kraft 1994, innebar att tidigare lagar som reglerat omsorgen om framförallt utvecklingsstörda ersattes av LSS (lagen om stöd och service till vissa funktionshindrade). ${ }^{5}$ Psykiatrireformen, som trädde i kraft 1995, innebar att kommunernas ansvar för personer med vissa typer av psykiska besvär utökades. Bland annat ålades kommunerna att erbjuda lämpliga boendeformer och stöd i hemmet för personer med omfattande psykiska funktionshinder. Vidare fick man betalningsansvar för patienter som efter tre månaders vård inom psykiatrin bedömdes som färdigbehandlade.

En annan betydelsefull förändring genomfördes 1991 då huvudmannaskapet för skolorganisationen i sin helhet överfördes till kommunerna. Tidigare hade detta delats mellan staten och kommunerna, men när de senare gavs ansvar för regleringen av lärarnas löne- och anställningsvillkor detta år fullbordades en utveckling mot kommunalt övertagande av ansvaret som inletts redan föregående årtionde. Samtidigt ersattes Skolöverstyrelsen av (det

5 LSS innebar visserligen en decentralisering av ansvar avseende vården av de psykiskt funktionshindrade, men lagen innehåller samtidigt en mycket tydlig precisering av de individuella rättigheterna vilket gör att det kommunala handlingsutrymmet, åtminstone formellt sett, är mer begränsat (Åström 2000). 
betydligt mindre) Statens skolverk, vilket i praktiken innebar en nedtoning av statens ambitioner att detaljstyra verksamheten till förmån för ett system där de nationella målen bevakas genom tillsyn, uppföljning och utvärdering.

Ett annat område där kommunernas ansvarstagande ökade under 1990-talet är den aktiva arbetsmarknadspolitiken (Regnér 2000). Parallellt med att utbudet av arbetsmarknadspolitiska program breddades under decenniet och antalet arbetslösa i aktiva åtgärder ökade, tilldelades kommunerna ett direkt ansvar för olika insatser riktade mot ungdomar (SOU 2000:3). År 1995 gavs kommunerna möjlighet att inom ramen för det så kallade kommunala utvecklingsprogrammet (KUP) teckna avtal om att ta över ansvaret för arbetslösa ungdomar mellan 18 och 20 år från staten. År 1998 utvidgades det kommunala ansvaret för arbetslösa ungdomar ytterligare genom införandet av den så kallade utvecklingsgarantin. Denna innebar att kommunerna frivilligt kunde ta på sig att ansvara för långtidsarbetslösa ungdomar 20 till 24 år och självständigt utforma arbetsmarknadsprogram för dessa ungdomar. Vid sidan om detta direkta övertagande av nya ansvarsområden förstärktes också kommunernas inflytande över arbetsmarknadspolitiken genom inrättandet av de nya arbetsförmedlingsnämnderna 1996.

Parallellt med ett ökat kommunalt ansvarstagande minskade också statens styrning av kommunernas verksamhet och prioriteringar. Här såg vi under 1980- och 1990-talen viktiga förändringar i den finansiella styrningen och i speciallagarnas konstruktion. I det förra fallet handlar det framförallt om statsbidragen, vilka otvivelaktigt utgör ett av de viktigaste styrmedlen staten har till sitt förfogande. Fram till 1993 dominerade så kallade specialdestinerade statsbidrag. Dessa utgick i huvudsak för driftsändamål, för att finansiera verksamhet på bestämda områden och inte sällan med detaljerade föreskrifter om hur pengarna skulle utnyttjas. Under 1993 avskaffades de flesta av dem till förmån för ett system med mer generella bidrag (prop. 1991/ 92:150). Kommunerna tilldelades en klumpsumma pengar, en så kallad "påse», för att självständigt kunna prioritera inom ramen för sina åtaganden. Motiveringen till förändringen var att generella bidrag - i samklang med den nya kommunallagens anda - skulle skapa bättre förutsättningar för utveckling och förnyelse i kommunerna samt bidra till en bättre samordning och ett effektivare resursutnyttjande. Områden där de specialdestinerade bidragen ersattes av generella var bl.a. skolan, barnomsorgen, vård och omsorg, färdtjänst och svenskundervisning för invandrare. I runda tal 85 procent av de samlade statsbidragen stoppades $i$ "påsen«. Förändringarna innebar att staten avstod en del av sina tidigare möjligheter att påverka fördelning och inriktning $i$ kommunsektorn.

Lagstiftningstekniken har under de senaste decennierna genomgått väsentliga förändringar såtillvida att ramlagar allt mer kommit att ersätta detaljreglering, en utveckling som i allt väsentligt inneburit en ökad frihet för kommunerna. Ramlagarnas gyllene årtionde, med avseende på när de infördes, var i synnerhet 1980-talet (Montin \& Elander 1995). Med ramlagarna har i många fall den enskildes lagreglerade

Åke Bergmark \& Renate Minas: Decentraliserad välfärd eller medborgerliga rättigheter? 
rätt till olika former av stöd försvagats.

Ett exempel på det är Socialtjänstlagen där kommunernas tolkningar av begreppet "skälig levnadsnivåı inte bara varierat kommunerna emellan, utan också i många fall avvikit från de nivåer som staten via Regeringsrättens domar fastslagit. Fram till revideringen av Socialtjänstlagen 1998 skulle vad som var skälig levnadsnivå, när det gäller ekonomiskt bistånd, bedömas med hänsyn till den allmänna standardutvecklingen och fixeras i ett samspel mellan rättspraxis och preciseringar i Socialstyrelsens allmänna råd. Vid ingången av 1990-talet gjordes de senare med utgångspunkt från Konsumentverkets kostnadsberäkningar för hushållsutgifter och skrevs regelmässigt upp baserat på utvecklingen av basbeloppet. Många kommuner tillämpade dock vid denna tid en väsentligt lägre norm, bland annat den så kallade "Tingsrydsnormen" där vissa typer av kostnader var bortplockade (Socialstyrelsen 1996). Rättspraxis anpassades sedan till denna lägre nivå 1994 då Regeringsrätten i en dom fastslog att kommunerna hade rätt att använda sig av »Tingsrydsnormen", och ett stort antal kommuner gick också därefter över till denna. Perioden fram till 1998 - då bestämmelserna om det ekonomiska biståndet i Socialtjänstlagen reviderades (se nedan) - kännetecknades sedan av att många kommuner antog normer som låg på en ännu lägre nivå, en mängd överklaganden där förvaltningsdomstolarna underkände kommunernas beslut och ett antal fall där det till och med genomfördes utmätning av kommunen för att den enskilde skulle få vad han var berättigad till (Johansson 2001).

\section{Recentralisering}

Även om decentraliserande beslut dominerat utvecklingen under den aktuella tidsperioden, så saknas inte exempel på förändringar med motsatt innebörd. Merparten av sådana recentraliserande beslut kan dateras till andra halvan av 1990-talet och framåt och gäller i högre utsträckning utökad statlig styrning än återtagande av huvudmannaskap. ${ }^{6}$ Ett mycket tydligt exempel utgörs av statsbidragens utveckling, där staten i ökad utsträckning börjat utnyttja mer riktade bidrag för att stimulera tillväxt och kvalitetshöjningar på särskilda områden. Specialdestinerade statsbidrag har återkommit i form av tidsbegränsade riktade bidrag, ofta kombinerade med särskilda delegationer i syfte att driva/understödja utvecklingen i en given riktning (Fi 2003:02). ${ }^{7}$ Särskilt vanligt har satsningar på skolområdet varit, genom t.ex. ITIS (delegation för särskild satsning på IT i skolan) eller de s.k. Wärnersson-pengarna, ett villkorat statsbidrag

6 Exempel på det senare finns dock. Det gäller bland annat bostadsbidrag och bostadstillägg för pensionärer där ansvaret 1994 övergick från kommunerna till staten. Ett annat exempel är bildandet av Statens Institutionsstyrelse samma år, som genomfördes i samband med att ansvaret för de tidigare ungdomsvårdsskolorna flyttades tillbaka till staten.

7 Återgången till specialdestinerade bidrag illustreras också tydligt av att mängden anslag från stat till kommun ökar. Mellan 1993/1994 och 2001 ökade de från 62 till 127, dvs. mer än fördubblades. Anslagen är nästan undantagslöst verksamhetsanknutna, dvs. specialdestinerade (Statskontoret 2003). 
som betalas ut mellan 2001 och 2007 för att stärka personaltätheten inom skolor och fritidshem. Liknande satsningar har genomförts inom förskolan. Från kommunernas sida har det framförts kritik mot denna återgång till vad man uppfattar som en detaljerad styrning av den kommunala verksamheten (Sveriges Kommuner och Landsting 2005).

Under 1990-talet har vidare staten kringskurit kommunernas handlingsutrymme i andra ändan, det vill säga när det gäller möjligheterna att höja kommunalskatten. Perioden 1991 till och med 1993 tog sig detta uttryck genom ett kommunalt skattestopp. Under 1994 utgick en ersättning på sammanlagt 4,2 miljarder kronor till de kommuner som avstod från att höja skatten. År 1995 avstod staten från att aktivt motverka skattehöjningar, och följdriktigt ökade den genomsnittliga kommunala skattesatsen påtagligt detta år. Under andra hälften av decenniet gjorde staten, bl.a. i finansplanerna, tydliga markeringar att man förbehöll sig rätten att reagera om kommunernas konsumtionsutrymme utvecklades på ett sätt som stod i strid med den generella samhällsekonomiska utvecklingen (Riksrevisionsverket 1996a). För perioden 1997 till 1999 gällde också att kommuner och landsting som höjde sina skatter förlorade statsbidrag motsvarande hälften av de ökade skatteintäkterna.

Vid sidan om den finansiella styrningen har också detaljregleringar på olika sätt påverkat det kommunala handlingsutrymmet och inneburit förskjutningar av a) ambitionsnivå och $\mathrm{b}$ ) den enskildes rätt. Det kanske tydligaste exemplet på ambitionshöjning är förändringen av skollagen
1995 där kommunerna »utan oskäligt dröjsmål ålades att bereda plats i förskolan till alla barn mellan ett och tolv år, vars föräldrar förvärvsarbetar eller studerar. Eftersom inte full kompensation utgick för de kostnadsökningar som detta medförde, uppfattades åtgärden som ett brott mot den så kallade finansieringsprincipen - det vill säga att kommunerna inte skulle påföras nya uppgifter eller utökat ansvar utan att de gavs möjlighet att finansiera dessa med annat än höjda skatter. Ett annat område där man också kan peka på en statligt initierad höjning av ambitionsnivån är omsorgen om funktionshindrade, där införandet av lagen om stöd och service till vissa funktionshindrade (LSS) och lagen om assistansersättning (LASS) inte bara innebar ökade kommunala åtaganden, utan också en förstärkning av den enskildes rätt (Åström 2000).

Också införande av maxtaxa inom äldreomsorg och förskola under 2002, där man genom avgiftstak och förbehållsbelopp reglerat vilka avgifter kommunerna (högst) kan ta ut av dem som nyttjar verksamheterna, måste räknas till de recentraliserande besluten. Med maxtaxan minskar dels kommunernas möjlighet att lägga en större del av finansieringen på brukarna och dels möjligheterna att via priset på tjänsten hålla efterfrågan nere.

En principiellt viktig inskränkning av det kommunala handlingsutrymmet när det gäller ekonomiskt bistånd genomfördes också 1998 i samband med att Socialtjänstlagen reviderades. Den så kallade riksnorm som då infördes minskade kommunernas möjligheter att sänka ersättningsnivåerna, åtminstone för delar av det

Åke Bergmark \& Renate Minas: Decentraliserad välfärd eller medborgerliga rättigheter? 
ekonomiska biståndet. Riksnormen utgörs av ett schablonbidrag för ett visst antal utgiftsposter och bestäms av regeringen och gäller lika för landets alla kommuner. Det minskade kommunala handlingsutrymmet kompenserades dock genom att kommunerna fick frihet att välja huruvida man skulle bevilja bistånd för ett antal poster vilka tidigare i regel utgjort accepterade utgifter inom ramen för »en skälig levnadsnivåu.

Garantier är en annan strategi för att åstadkomma en likvärdig samhällsservice, där medborgare som inte får tillgång till en service eller tjänst inom en viss tidsperiod $i$ hemkommunen ges rätt att söka denna i en annan kommun eller landsting på bekostnad av hemkommunen/landstinget. Garantierna skall utgöra incitament för kommunerna och landstingen att förbättra sin verksamhet. Vårdgaranti är ett samlingsnamn för behandlingsgaranti, besöksgaranti och tillgänglighetsgaranti inom hälso- och sjukvården. En utökad vårdgaranti infördes 2005. Vårdgarantin omfattar sedan dess all planerad vård inom den specialiserade vården - såväl besök som behandlingar med undantag för utredningar (t.ex. röntgen). Den omfattar också första kontakt och läkarbesök inom primärvården.

Vid sidan av de beslut som har en mer uppenbar de- eller recentraliseringskaraktär finns ett antal andra utvecklingsdrag som inte omedelbart kan karakteriseras i sådana termer, men som otvivelaktigt påverkar relationerna mellan stat och lokalsamhälle. Dit hör exempelvis utformningen av de kommunala skatteutjämningssystemen. Under början av 1990-talet infördes ett nytt system som innehöll ett garante- rat grundbelopp för att garantera kommunerna en viss lägsta skattekraft och ett tillägg eller avdrag till grundbeloppet för att kompensera för strukturella skillnader. En av grundtankarna var att statsbidrag i huvudsak bör ges som generella bidrag. En revidering av systemet genomfördes 1996, med innebörden att omfördelningen inte längre gjordes genom att en kommuns skatteinkomster tillfördes en annan. Istället svarade staten formellt för utjämningskostnaderna, men finansierat genom en utjämningsavgift uttagen från kommuner med hög skattekraft och gynnsamma strukturella förutsättningar. Mottagare av bidragen var kommuner med relativt låga skatteinkomster respektive höga strukturellt betingade kostnader. Sammantaget har de möjligheter som kommuner med hög skattekraft tidigare haft att ta ut en väsentligt lägre kommunalskatt än andra begränsats med omläggningarna av skatteutjämningssystemet.

Vi kan också konstatera att i det förslag om en reformering av den regionala strukturen som lades av Ansvarskommittén under våren 2007 fanns inslag av såväl desom recentralisering (SOU 2007:10). Att ersätta dagens 21 landsting med 6-9 regionkommuner måste otvivelaktigt ses som ett sätt att avlägsna beslutsfattandet från den lokala nivån, medan överflyttning av ansvar från stat till de nya regionkommunerna när det gäller sådant som infrastruktur och regionplanering får betraktas som en motsatt rörelse. Noterbart är dock att staten enligt förslaget bibehåller tillsyn via länsstyrelserna och att kommittén också förordar en tydligare struktur när det gäller statens styrning av kommunerna. 


\section{Kommunala variationer}

En av de mest grundläggande frågorna i kölvattnet på maktförskjutningar mellan stat och kommun är i vilken utsträckning detta inverkar på kommunala skillnader avseende utbud, tillgänglighet och kvalitet $\mathrm{i}$ vård och service. Huruvida kommunala variationer i sig är önskvärda eller acceptabla är ytterst en politisk fråga, men att förutsättningarna att få stöd och hjälp skiljer sig åt beroende på var i landet man bor är, som framgått ovan, en av de allra vanligaste invändningarna mot ett omfattande kommunalt självstyre. Ett vanligt grundantagande är annars att decentralisering i termer av utökat lokalt handlingsutrymme ökar de interkommunala variationerna (Powell \& Boyne 2001). Andra utgår från att det pågår en process av ökad kommunal enhetlighet/likformighet också parallellt med en försvagad statlig styrning (Petersson 2006). Inget av perspektiven har emellertid något entydigt stöd i empiriska iakttagelser. Utvecklingen är i realiteten ytterst sammansatt och tydliga mönster svåra att identifiera.

Hur har då variationerna kommunerna emellan utvecklats under senaste decennierna? Någon heltäckande eller kontinuerlig uppföljning av detta existerar inte, men valda delar av utvecklingen kan återspeglas med hjälp av studier genomförda vid olika tillfällen. Ser vi till utvecklingen under 1970- och 1980-talen förefaller den huvudsakliga trenden vara minskade skillnader. Johanssons $(1982,1983)$ analyser av barnomsorg, äldreomsorg, kulturverksamhet och kommunala kostnader visar tämligen entydigt på minskad variation under 1970talet. Stjernquist och Magnusson (1988) gör liknande iakttagelser för perioden 1975 till 1985. Trydegård (2000) beskriver också en generellt minskad variation för äldrevården 1976-1992, även om utvecklingen till och från gått åt olika håll under perioden.

För 1990-talet gäller generellt att inga entydiga mönster kunnat urskiljas. Ökade variationer har kunnat konstateras inom områden som äldrevård, socialbidrag, kostnader i grundskolan för läromedel och elevvård samt personaltäthet inom förskolan (Trydegård a.a., Bergmark 2001). Minskade variationer hittar vi i kostnader per elev i grundskolan, socialtjänstens barn- och ungdomsvård samt kostnader per barn i barnomsorgen. Lärartäthet i skolan, insatser för funktionshindrade samt åtgärder inom missbrukarvård beskriver mer oförändrade förlopp (Bergmark a.a., Regeringen 2000). Organisatoriskt föreligger också en mängd parallella processer som innehåller såväl rörelser mot ökad likformighet (t.ex. en generellt ökad specialisering inom individoch familjeomsorgen) som ökad divergens (den kommunala nämndstrukturen) (Bergmark \& Lundström 2005).

\section{Diskussion och sammanfattning}

I takt med att nationalstatens primat utmanas av såäl ökat lokalt inflytande som förflyttning av makt till supranationella organ har frågan om förutsättningarna för välfärdspolitikens inriktning fått en delvis annan innebörd än tidigare. I många länder tilldelas regioner och kommuner ett direkt ansvar för sådant som tidigare varit statliga angelägenheter och genom den Europeiska

Åke Bergmark \& Renate Minas: Decentraliserad välfärd eller medborgerliga rättigheter? 
unionen begränsas på olika sätt spelrummet för den nationella politiken. Parallellt uppstår nya typer av nätverk och samarbeten som bidrar till att nya institutionella mönster etableras (se t.ex. Gossas 2006).

Rescaling - vilket är ett begrepp som används för att beskriva vertikal omfördelning av makt och ansvar - utgör således bara en av ett flertal rörelser som för tillfället påverkar den välfärdspolitiska spelplanen. I föreliggande artikel har fokus primärt riktats mot relationen stat-kommun och mot olika uttryck för hur makt- och ansvarsfördelning dem emellan utvecklats. Såväl i Sverige som internationellt har det på många håll funnits en väletablerad föreställning om att vi befinner oss mitt i en mer eller mindre irreversibel trend i riktning mot ökad decentralisering. Många av de viktigaste förändringarna i Europa har också otvivelaktigt haft sådana förtecken. En mer detaljerad granskning av aktuella händelser och historiska förlopp manar dock till en viss försiktighet när det gäller att avskriva nationalstaten och att extrapolera det ökade lokala inflytandet.

I en detaljerad översikt av hur det norska politiskt-administrativa systemet förändrats under perioden 1947-2003 konstaterar Laegrid et al. (2003) att de- och recentraliseringsrörelserna över tid beskriver ett närmast cykliskt förlopp, där utvecklingen i en riktning efter en viss tid resulterar i en motreaktion och att ett slags balans därmed upprätthålls i ett längre perspektiv. Vilken generaliserbarhet en sådan iakttagelse har idag eller i ett internationellt perspektiv må vara osagt, men eftersom den norska välfärdsstaten i många avseenden liknar den svenska är resultatet intressant. Vi har ovan berört vilka argument som anförts när det gäller centraliserade och decentraliserade system och vilka värden som anses gå förlorade när utvecklingen går för långt åt det ena eller andra hållet. Att svängningar sker över tid kan då bero på att vissa värden anses hotade när processen når en viss punkt och att motreaktioner då provoceras fram. Kettl (1983 s. 169) beskriver det som att "Decentralization is the usual prescription for troubled centralized systems, centralization for decentralized ones».

Huruvida den ovan beskrivna utökningen av recentraliserande beslut från mitten av 1990-talet och framåt skall ses som en cyklisk svängning eller inte, tilllåter vare sig vårt material eller längden på den tidsperiod vi behandlar några säkra slutsatser om. Ett par saker kan dock sägas om utvecklingsdragen här. För det första kan vi konstatera att de recentraliserande beslut som fattats i allt väsentligt handlat om att förstärka den statliga styrningen, inte om att återföra det exekutiva ansvaret till den statliga organisationen. För det andra så handlar det om beslut med mycket olika grad av räckvidd och tvingande kraft. Medan exempelvis riksnormen för socialbidrag och skyldigheten att erbjuda förskola är uttryck för en mycket tydlig styrning så är de stimulanspaket som introducerats med Persson- eller Wärnerssonpengar exempel på en mycket mer kompromissartad strategi, där staten agerar i ett bestämt syfte men där man samtidigt söker respektera det kommunala självstyret.

För det tredje finns det anledning att peka på att den recentraliserande fasen $\mathrm{i}$ allt väsentligt sammanfaller med regeringen Persson och med en period där staten, 
åtminstone inledningsvis, tvingats till impopulära besparingar på olika områden. Motiven till besluten kan sannolikt sökas $i$ en oro för att vissa kommuner tenderat att sänka sina ambitioner när det gäller olika välfärdstjänster till en nivå som inte bara understigit statens uttalade mål, utan också riskerat att slå tillbaka på densamma $i$ en period när välfärdens kvalitet varit $i$ fokus för den allmänna debatten. Det förefaller med andra ord inte som om de korrigerande beslut som vidtagits primärt syftat till att minska de kommunala variationerna, utan att det i första hand handlat om att garantera att vissa lägstanivåer när det gäller service, tillgänglighet eller individuella rättigheter inte äventyras.

Den Kommunala Förnyelsekommittén konstaterade i sitt slutbetänkande att decentraliseringen från stat till kommun inneburit oklarheter i ansvarsfördelningen på olika områden (SOU 1996:169). Staten har hänvisat till kommunernas ansvar och kommunerna till de resursbrister man ställts inför och som, åtminstone till viss del, varit en effekt av den statliga politiken gentemot kommunerna. Dessa mönster uppträder alltjämt, men möjligen kan man se de statliga recentraliseringsbesluten från mitten av 1990-talet som ett uttryck för att staten alltjämt uppfattar sig som den yttersta garanten för välfärdstjänsternas kvalitet och tillgänglighet. Att besluten i hög utsträckning sammanfaller med reger- ingen Persson ger dock, mot bakgrund av det senaste regeringsskiftet, anledning till försiktighet när det gäller att skriva fram aktuella trender.

Avslutningsvis finns det anledning att reflektera över den svenska utvecklingen i ett europeiskt perspektiv. Preliminära resultat från ett pågående komparativt projekt där vi är involverade antyder att också utvecklingen på europeisk grund är sammansatt och inte, som emellanåt hävdas, entydigt beskriver en rörelse mot ökad decentralisering. På vissa håll, som t.ex. i Spanien, har det otvivelaktigt skett en utveckling som inneburit att nationalstaten försvagats och att regioner/kommuner inte bara fått ett ökat ansvar för välfärdspolitikens utförande, utan också för dess inriktning. Många gånger drivs utvecklingen här mer av mikro-nationalistiska krafter än av överväganden avseende det lokala inflytandets fördelar i termer av effektivitet eller ändamålsenlighet (Hooghe \& Marks 2001). I andra länder saknas sådana förtecken, men här kan motiven till en ökad decentralisering sökas i allt från föreställningar om det lokala styrets demokratiska kvaliteter till en önskan att demontera den allomfattande välfärdsstaten. Motkrafter finns, som bl. a. den senare tidens utveckling $i$ Sverige exemplifierar, i synen på staten som bäst ägnad att vidmakthålla kvalitet och tillgänglighet i de välfärdstjänster som medborgarna erbjuds.

Åke Bergmark \& Renate Minas: Decentraliserad välfärd eller medborgerliga rättigheter? 


\section{Referenser}

Bache, I. \& Flinders, M. (2004) Multi-level governance. Oxford: Oxford University Press.

Bergmark, Å. (2001) „Den lokala välfärdsstaten? Decentraliseringstrender under 1990-talet». I M. Szebehely (red.) Välfärdstjänster $i$ omvandling, SOU 2001:52. Stockholm: Fritzes.

Bergmark, Å. \& Lundström, T. (2005) „En sak i taget? Om specialisering inom socialtjänstens individ- och familjeomsorg", Socialvetenskaplig tidskrift, 12, s. 125-148.

Birgersson, B.-O. \& Wallin, G. (1977) „Den kommunala självstyrelsen - en analys«, i SOU 1977:78, Kommunerna, bilaga 2. Stockholm: Fritzes.

Brenner, N. (2004) New state spaces: urban governance and the rescaling of statehood. Oxford: Oxford University Press.

Christensen, J. G. (2000) »The dynamics of decentralization and recentralization", Public Administration, 78, pp. 398-408.

De Vrijes, M. (2000) »The rise and fall of decentralization: A comparative analysis of arguments and practices in European countries", European Journal of Political Research, 38, pp. 193-224.

Flinders, M. (2001) The Politics of Accountability in the Modern State. London: Ashgate.

Gidlund, J. \& Jerneck, M. (2000) Local and regional governance in Europe: evidence from Nordic regions. Cheltenham: Edward Elgar Publishing Limited.

Gossas, M. (2006) Kommunal samverkan och statlig nätverksstyrning. Stockholm: Institutet för Framtidsstudier.

Gustafsson, A. (1999) Kommunal självstyrelse. Stockholm: SNS Förlag.

Hansen J. I. (1997) »The Scandinavian Model as seen from a local perspective». I J. Sipilä (red.) Social Care Services: The key to the Scandinavian Welfare Model. Aldershot: Avebury.

Henman, P. \& Fenger, M. (2006) Administering Welfare Reforms. International Transformations in Welfare Governance. Bristol: The Policy Press.

Hooghe, L. \& Marks, G. (2001). Multi-level governance and European integration. Lanham, Md.: Rowman \& Littlefield.
Hooghe, L. \& Marks, G. (2003) „Unraveling the Central State, but How? Types of Multi-level Governance", American Political Science Review, 97, pp. 233-243.

Jessop, B. (2002) The Future of the Capitalist State. Cambridge: Polity Press.

Jessop, B. (2005) »The Political Economy of Scale and European Governance", Tijdschrift voor Economische en Sociale Geografie, 96, pp.225230.

Johansson, H. (2001) I det sociala medborgarskapets gränsland. Rätten till socialbidrag under 1980- och 1990-talen. Lund: Arkiv.

Johansson, L. (1982) Kommunal Servicevariation. Rapport från Kommunaldemokratiska kommittén, 11. Stockholm: Liber/Allmänna Förlaget.

Johansson, L. (1983) „Kommunal Servicevariation". I L. Strömberg \& J. Westerståhl (red.) De nya kommunerna. En sammanfattning av den kommunaldemokratiska forskningsgruppens undersökningar. Stockholm: Liber.

John, P. (2004) Local Governance in Western Europe. London: Sage.

Kettl, D. (1983) The Regulation of American Federalism. Baton Rouge and London: Louisiana State University Press.

Laegrid P., Polland V., Roness P. \& Ågotnes J-E. (2003) The Structural Autonomy of the Norwegian State, 1947-2003. Paper presented at the Seminar on the Study of Public Sector Organizations, Public Managment Instuitute, Katholieke Universiteit Leuven, May 2-3.

Leibfried, S. \& Pierson, P. (1995) European social policy: between fragmentation and integration. Washington, D.C.: Brookings Institution.

Lidström, A. (1991) Discretion. An Art of the Possible. Umeå: Umeå universitet, Statsvetenskapliga institutionen.

Lidström, A. (2003) Kommunsystem i Europa. Malmö : Liber.

Lidström, A. \& Kolam, K. (2003) Kommunal självstyrelse $i$ förändring - ansvarsfördelningen mellan stat och kommuner 1974-2002. Förslag till riksdagen 2002/03:RR21, bilaga 6 . 
Lundin, M. \& Skedinger, P. (2000) Decentraliserad arbetsmarknadspolitik- effekter av ett ökat kommunalt inflytande $i$ arbetsförmedlingsnämnderna. Uppsala: Institutet för arbetsmarknadspolitisk utvärdering (IFAU).

Lundquist, L. (1972) Means and goals of political decentralization. Lund: Studentlitteratur.

Mahon, R. (2006) „Of Scalar hierarchies and welfare redesign: child care in three Canadian cities", Transactions of the Institute of British Geographers, 31, pp. 452-466.

Montin, S. (1996) Kommunala förnyelseproblem. I SOU 1996:169. Stockholm : Fritzes.

Montin, S. \& Elander, I. (1995) "Citizenship, Consumerism and Local Government in Sweden", Scandinavian Political Studies, 18, pp. 25-51.

Nilsson, L. (2004) „Vadan och varthän?». I L. Nilsson (red.) Svensk samhällsorganisation i förändring. Göteborg: Göteborgs universitet, SOMinstitutet.

Nilsson, L. \& Westerståhl, J. (1997) »Lokal självstyrelse i Sverige«. I S. Jönsson et al. (red.) Decentraliserad välfärdsstat. Demokrati, effektivitet och service. Stockholm: SNS Förlag.

Page, E. (1991) Localism and centralism in Europe. Oxford: Oxford University Press.

Panican, A. \& Sunesson, S. (2004) Det skiftande värdet av rättigheter. Lund: Lunds Universitet, Socialhögskolan.

Petersson, J. (2006) Prioriteringar och processer inom socialtjänsten. Malmö: Bokbox Förlag.

Petterson, O. (2001) Kommunalpolitik. Stockholm: Norstedts Juridik.

Pierre, J. (1987) „Decentraliseringens politik och politikens decentralisering". I B. Rothstein (red.) Politik som organisation. Förvaltningspolitikens grundproblem. Stockholm: SNS Förlag.

Pierre, J. \& Peters. G.B. (2000) Governance, Politics and the State. Basingstoke: MacMillan Press.

Pierson, P. (2004) Politics in time: history, institutions and social analysis. Princeton: Princeton University Press.

Pierson, P. (1995) „Fragmented Welfare States: Federal Institutions and the Development of Social Policy", Governance, 8, pp. 449-478.

Pollitt, C. (2005) „Decentralization: a central con- cept in contemporary public management". IE. Ferlie, L. Lynn and C. Pollitt (red.). The Oxford Handbook of Public Management, Oxford: Oxford University Press.

Powell, M. \& Boyne, G. (2001)»The spatial strategy of equality and the spatial division of welfare", Social Policy and Administration, 35, pp. 181194.

Premfors, R. (1996) Reshaping the Democratic State: Swedish Experiences in a Comparative Perspective. Stockholm: SCORE.

Prop. 1973:90. Författningsreformen. Stockholm.

Prop. 1991/92:150. Förslag till slutlig reglering av statsbudgeten för budgetåret 1992/9.

Putnam, R. (1993) Making Democracy Work: Civic Traditions in Modern Italy. Princeton: Princeton University Press.

Rauch, D. (2005) Institutional Fragmentation and Social Service Variations. Diss. Umeå: Umeå University, Department of Sociology.

Regnér, H. (2000) "Ändrade förutsättningar för arbetsmarknadspolitiken?». I J. Fritzell (red.), Välfärdens förutsättningar. Arbetsmarknad, demografi och segregation, SOU 2000:37. Stockholm: Fritzes.

Regeringen (2000). Utvecklingen inom den kommunala sektorn. Regeringens skrivelse 1999/2000: 102. Stockholm.

Riksrevisionsverket (1996a). Förhållandet stat - kommun. Rapport 1996:2. Stockholm: RRV.

Riksrevisionsverket (1996b). Statlig tillsyn - ett förvaltningspolitiskt styrmedel. Rapport 1996:10. Stockholm: RRV.

Rothstein, B. (red) (2001) Politik som organisation: förvaltningspolitikens grundproblem. Stockholm: SNS.

Seip, A-L. (1991) »Velferdskommunen og velferdstrekanten - et tillbakablikku. I A. Nagel (red.) Kommunenes rolle $i$ utviklingen av velferdsstaten. Bergen: Alma Mater.

Sharpe, L.J. (1970) "Theories of local government", Political Studies, 18, pp. 153-174.

Sharpe, L. J. (1988) »The growth and decentralisation of the modern democratic state", European Journal of Political Research, 16, pp. 222-239.

Segal, L. (1997) "The pitfalls of political decentra-

Åke Bergmark \& Renate Minas: Decentraliserad välfärd eller medborgerliga rättigheter? 
lization and proposals for reform. The case of New York City public schools", Public Administration Review, 57, pp. 141-149.

Socialstyrelsen (1996) Hur kan kommunerna minska kostnaderna för socialbidrag? Aktiv uppföljning. Stockholm: Socialstyrelsen.

SOU 1996:169. Förnyelse av kommuner och landsting: slutbetänkande. Stockholm : Fritzes.

SOU 1998:166. Regional frihet och statligt ansvar: en principiell diskussion: delbetänkande. Den parlamentariska regionkommittén (PARK). Stockholm: Fritzes.

SOU 1999:97. Socialtjänst i utveckling. Stockholm: Fritzes.

SOU 2000:3. Välfärd vid vägskäl. Stockholm: Fritzes.

SOU 2007:10. Hållbar samhällsorganisation med utvecklingskraft. Stockholm: Fritzes.

Statskontoret (2003) Statsbidragen till kommuner och landsting. En kartläggning och analys. Stockholm: Statskontoret.

Stjernquist, N. \& H. Magnusson (1988) Den kommunala självstyrelsen, jämlikheten och variationen mellan kommunerna. Stockholm: Civildepartementet.

Strandberg, U. (2000) "Service, medborgarskap eller social gemenskap?». I Självstyrelsen utmanad. Stockholm: Svenska Kommunförbundet.

Sunesson, S. (1999) „Medborgarrätten och det lokala självstyrets arrogans». I SOU 1999:40
Demokrati i den offentliga sektorns förändring. Stockholm: Fritzes.

Sveriges Kommuner och Landsting (2005) Statens detaljstyrning ur ett kommunalt perspektiv. Stockholm: Ansvarsprojektet.

Swyngedouw, E. (2004) "Globalisation or Glocalisation? Networks, Territories and Rescaling", Cambridge Review of International Affairs, 17, pp. 25-48.

Tideman, M. (2000) Normalisering och kategorisering: om handikappideologi och välfärdspolitik $i$ teori och praktik för personer med utvecklingsstörning. Lund: Studentlitteratur.

Treib O., Bähr H. \& Falkner G. (2005) „Modes of governance: a note towards conceptual clarification", European Governance Papers, nr.N-05-02 http://www.connex-network.org/ eurogov/pdf/egp-newgov-N-05-02.pdf

Trydegård, G B. (2000) Tradition, change and variation. Past and present trends in public old age care. Diss. Stockholm: Stockholms Universitet, Institutionen för socialt arbete.

Westerståhl, J. (1987) Staten, kommunerna och den statliga styrningen. Några principfrågor. Stockholm: Civildepartementet.

Åström, K. (2000) „Förändringar och förskjutningar i välfärdens rättsliga reglering under 1990-talet« I M. Szebehely (red.) Välfärd, vård och omsorg. SOU 2000:38. Stockholm: Fritzes.

\section{Summary}

\section{Decentralized welfare or citizenship rights? On redistribution of power and responsibility between nation- state and local government}

Subsidiarity is a concept that has gained ground during the last decades, partly because of its formal status in the EC treaty and partly because it captures deeply rooted ideas of anti-centralism and strives for subnational discretion. In short, the concept is based on the notion that government should take place at the lowest pos- 
sible level. Within nations, this means that the central state level enjoys no primacy in the distribution of authority or governance

Transformation of formal power from the central state to subnational levels is, however, far from being a new phenomenon. Decentralization of government has also been the prevailing trend ever since the Second World War, most pronounced in Europe but also present in most other parts of the world. Subnational spending has increased globally, and not least in the developing countries.

Until the mid 1990s, decentralization was unarguably also the dominant trend in Sweden. Distribution of authority in this direction has been a vital part of the growth of the welfare state and especially in the evolution of welfare services. Hence, Swedish municipalities are responsible for a substantial number of functions such as basic education, elderly care and individual and family services. In relation to most other countries municipal expenditure represents a significantly higher share of GDP as well as of total public spending. As to decision-making, the municipalities enjoy considerable discretion and local politicians act comparatively independently of national government.

In this article we describe and analyse transformations in territorial authority and local discretion regarding welfare services in the case of Sweden since the 1980s, by highlighting substantial shifts in national legislation and the modes of national control of local sector activities. In this, we focus on the inherent conflict between local government autonomy and nationally guaranteed citizenship rights. One finding is that local variation with respect to coverage rates and spending on different welfare services is substantial, although not increasing in times of increased decentralization.

Another central observation is that in the period after 1995 the number of steps towards decentralization has been low. Instead, we have seen an array of reforms and national government actions that have mainly served to redirect the initiative to the state. All the recentralizing measures that have been introduced during the last ten years have served to secure the political ambitions of national government at the expense of local self-regulation. With respect to content, their aim has been to defend availability, quality and minimum standards in welfare programmes where the development has taken a route that deviates from the objectives of national government. In that sense, the recentralizing steps may primarily be viewed as reactive moves rather than part of a comprehensive policy pursued by the state.

Åke Bergmark \& Renate Minas: Decentraliserad välfärd eller medborgerliga rättigheter? 